\title{
The Ma'atenu communication rituals of Pelauw Muslims community
}

\section{Komunikasi ritual Ma'atenu masyarakat Muslim Pelauw}

\author{
Sulaeman $^{1}$, Kamaruzzaman ${ }^{2}$, \& Mahdi Malawat ${ }^{3}$ \\ ${ }^{1,3}$ Faculty of Ushuluddin and Da'wah, Institut Agama Islam Negeri Ambon \\ ${ }^{2}$ Faculty of Ushuluddin Adab and Da'wah, Institut Agama Islam Negeri Lhokseumawe \\ Address: ${ }^{1,3}$ Jalan Dr. H.Tarmidzi Taher, Ambon, Mollucas 97128 \\ ${ }^{2}$ Jalan Medan-Banda Aceh, Muara Dua, Lhokseumawe, Aceh 24352 \\ E-mail: sulaeman@iainambon.ac.id
}

\begin{abstract}
The purpose of this research is to analyse of the symbols Ma'atenu ritual communication process of Pelauw Muslims community. Ma'atenu is an integral part of rituals society, held as the fusion of Islamic teachings interaction with the values of local wisdom. The rituals started with prayer using various media such as machetes, swords, tifa, tambourine, and immune test to from as power of ancestral spirits by cutting, slicing and stabbing body parts such as stomach, chest, hands, feet, neck, cheeks, tongue, and head. This research employed a subjective interpretive paradigm with ethnography communication approach by Dell Hymes based on symbolic interaction perspective. Involving 17 informants with one ma'ahala lahat, one ma'ataru ame, three kings of the country, three mothers and/or wives, and the remaining nine practitioners of ritual communication actions from the western, southern and eastern sectors chose purposively. The study finds that Ma'atenu communication event act as symbols of the ritual home clan (small clan, parent clan, and merger clan), the sacred meal, self-cleaning action ritual communication action, self-cleaning action, and fabric wreath. Any communication event represents symbols of devotion, struggle, disposal of a bad attitude, immunity and power, and self-recovery. Communication consists of pattern between communication components that forms pattern within Ma'atenu rituals appear in plea to God, veneration of ancestral spirits, and social solidarity of Muslims in Pelauw.
\end{abstract}

Keywords: rituals communication; Ma'atenu; Pelauw Muslims

\begin{abstract}
Abstrak
Tujuan penelitian ini adalah menganalisis komunikasi ritual Ma'atenu masyarakat Muslim di Pelauw. Ma'atenu, bagian integral ritual masyarakat, keterpaduan interaksi hubungan ajaran Islam dengan nilai-nilai kearifan lokal, diawali do'a selamatan yang dipadukan dengan media seperti parang, pedang, tifa, rebana, sampai kepada bentuk pengujian kekebalan dan keperkasaan diri dari kekuatan roh leluhur dengan memotong, mengiris dan menikam perut, dada, tangan, kaki, leher, pipi, lidah, dan kepala. Penelitian ini menggunakan paradigma interpretatif subjektif dan pendekatan etnografi komunikasi dengan metode speaking dari Dell Hymes berdasarkan perspektif interaksi simbolik. Melibatkan tujuh belas informan dengan satu orang ma' 'ahala lahat, satu orang ma'ataru ame, tiga orang raja negeri, tiga orang ibu dan atau istri, dan selebihnya sembilan orang pelaku tindakan komunikasi ritual dari sektor barat, selatan dan timur dipilih secara purposif. Hasil penelitian menemukan bahwa peristiwa komuniksi Ma'atenu sebagai simbol ritual rumah marga, makan keramat, pembesihan diri, tindakan komunikasi ritual, dan pengalungan kain. Setiap peristiwa komunikasi tersebut memiliki pemaknaan simbol pada pengabdian, semangat perjuangan, membuang sifat tidak baik, kekebalan dan keperkasaan diri, serta pemulihan kondisi diri. Peristiwa komunikasi memiliki pola hubungan antara komponen komunikasi yang membentuk pola komunikasi dalam ritual Ma'atenu berupa permohonan kepada Allah Subhanahu wa Ta'ala, penghormatan roh leluhur, dan solidaritas sosial sesama masyarakat muslim di Pelauw.
\end{abstract}

Kata kunci: komunikasi ritual; Ma'atenu; Muslim Pelauw

\section{Introduction}

Indonesia is known as archipelago countries. One of the provinces in the eastern part of Indonesia is Maluku, an island with a high population density in the coastal area with diverse tribes, languages, religions, races and between groups. Maluku people characterised by pluralism combined with the 
diversity of local wisdom established through the community interaction. Diversity of local wisdom has evolved within the community, internalised into tradition and with its values and benefits for local people (Kasnadi 2017:151). Local wisdom imposed by the community and functioned as guidance for their Maluku people lives.

Local wisdom created to build, preserve and strengthen the recognition of cultural identity. Communities created local wisdom and positioned their lives amid local wisdom for presentation purpose (Leuape \& Dida 2017:148). The community has a genealogy that rules generations of Maluku tribes, inhabiting certain places with a prevailing system of values and rules based on unwritten local wisdom. For instance, the community in Pelauw Village, Pulau Haruku District, Central Maluku Regency, Maluku Province. The Pelauw community is a traditional community that adheres the teachings of Islam. They live in the coastal areas of the mountains and the ocean. The community is proof of local wisdom in Indonesia is plentiful of the values of diversity and plurality. The Pelauw people hold Ma'atenu, a local tradition, every three years.

Ma'atenu ritual also knows as cakalele, consists of two syllables, ma'a and tenu. Ma' $a$ in the traditional language of Pelauw means let's, and tenu means to test. Ma'atenu implies "Let us test immunity from unconscious ancestral spirit forces," accompanied by celebration prayers, equipped with tools such as machetes, swords, drums, tambourines. The rites also include a more complex forms of solidarity performed in the central mosque and baileo. Ma'atenu is a ritual that combines the relationship between the interaction of Islam and the local wisdom Pelauw people. The ritual combines the understanding and knowledge of plea to Allah Subhanahu wa Ta'ala and respect for ancestors with interaction and communication with the Pelauw community. Therefore, the authors will explore the case of Pelauw people through an ethnographic approach.

"Ethnography is a study to understand how people interact and cooperate through observable phenomena in their daily lives, aimed at describing a culture as a whole, all aspects of culture, both material in nature such as cultural artefacts (tools, clothing, buildings) as well as abstract, such as experiences, beliefs, norms, and group value systems" (Mulyana 2018:2).

According to communication science, the ethnographic approach will lead to a more specific discussion, focusing on community strategic position with local wisdom, especially related to the relations with their ancestors. In communication ethnography, understanding communication cannot be separated from a series of concepts of language, communication and culture. However, communication is the focus of human interaction by using language in certain cultures, such as the statement of Hymes (1962).

The ethnography of communication is the patterns of communication within a group (Littlejohn \& Foss 2010:194). When having communication, individuals will be influenced and governed by the sociocultural rules from which they originate and where they communicate. Ethnography of communication sees the act of communication as behaviour arising from the integration of the three skills possessed by individuals, namely linguistic, interaction, and cultural skills. These three skills are communication competencies, emphasises on its ritual communication. Ritual communication is a method to observe human identity as individuals, members of social communities, and as an element of the universe. Individuals who perform ritual communication confirm their commitment to family, ethnic, national, ideological, or religious traditions, as stated by Mulyana (2018:3). The ritual communication provides an understanding of knowledge with the diversity of local wisdom based on actions on interaction carried out by indigenous peoples (Kuncoroyakti 2018:624).

Rituals in communication ethnography refer to the perspective of transactional communication where individuals who communicate actively act as sources of information, conveying and interpreting messages in the activities. As Mulyana stated, "The ritual communication is related to expressive communication," (Sulaeman \& Malawat 2018:35). Expressive communication performed collectively as a model of action used to express social relations. Ritual action appears on several forms that regarded as symbols of guidance in social relations, orders, and social institutions where the ritual performed, such as Ma'atenu. 
Ma'atenu is a communication ritual of the Pelauw people that uniquely performed by a group by cutting, slicing and stabbing the stomach, chest, hands, feet, neck, cheeks, tongue, and head with machetes, swords, and or other sharp objects. Such acts require an understanding of the relationship between humans and rituals. The comprehension begins with an understanding of their local wisdom. Machetes, swords and other sharp objects as ritual media, especially in the context of indigenous peoples, are influenced and determined by the unconscious ability to test the immunity and power of ancestral spirits.

Studies on ritual communication and its relations with ethnographic theory and symbolic interaction have been conducted for many times in Indonesia. Studies from Foni (2004) on the customary act of Atoni Pah Meto found that farming method utilised Atoni Pah Meto Tunoaba Timor dry land as a ritual cycle in East Nusa Tenggara. Rumahuru et al. (2012) researched about the media construction of Ma'atenu identity and rituals of the Hatuhaha Muslim community in Pelauw. Sakka (2015) conducted a study about Ma'atenu dancing media on Haruku Island, Central Maluku Regency.

Previous research has revealed similarities in the aspects of methods and approaches used to the phenomenon of a reality experienced by the Pelauw Muslim communities. The research that will be carried out has a significant difference from previous research, bearing in mind the aspects of the focus of the study, the purpose of the study and the characteristics of the subjects under study have fundamental differences that are quite comparable. Previous research of this type can also be used as a reference for this research, especially in the discussion of research findings that will be carried out after data has been collected and data processing to be used as material for decision making and verification of the Ma'atenu ritual communication.

Pelauw people live as indigenous communities and invariably bound by standard regulations and or norms of local wisdom of Ma'atenu. The cycle of carrying out ritual communication aims to reflect upon their existence as indigenous peoples. Ma'atenu always started with ritual communication events that gather people at the clan house (small clan, parent clan, and merging clans), sacred tombs, self-cleaning actions, ritual communication acts and giving fabric to ritual communication performers. Rituals in Ma'atenu communication had started from the journey too small clan houses. The peak of rituals conducted in the square of the mosque and baileo. The places are believed as the proper area to plea to God, to respect, and to uphold solidarity of people. In conducting the event, there is a high consideration of historical basis in narrating people immunity and courage in enacting Islam ideological teaching, as well as rejecting the presence of the Portuguese and the Dutch in the form of communication acts of Hatuhaha's ancestral war.

In performing Ma'atenu ritual communication the performer selected by the clan chief, Afterwards, the performer proceeds to the Ma'atenu ritual implementation team of clan representatives in Pelauw. Performers should be originated from Pelauw, even though they are currently not based on Pelauw, have a secure emotional attachment, have physical and mental health, obtain the blessing and or consent from family and wife. The performer of the ritual should also maintain verbal communication and the psychology of communication to community-family. They required to shave their hair from the head. They also should have the ability to follow the actions of cutting, slicing, and stabbing limbs through sharp objects. The Ma'atenu communication ritual uniqueness becomes the pivot point of this research. We employ Herbert Blummer's symbolic interactionism theory that portrayed social reality created by humans through the interaction of meanings that conveyed symbolically (Mulyana \& Sulaeman 2016:137). Symbols created from the interconnected essence of human beings (Sulaeman \& Sulastri 2017:249-250). The symbolic interaction perspective highlights how Pelauw people carry out their ritual communication activities. This research starts to observe communication event as part of the ritual communication process by qualitative research (Sulaeman 2018:665) in an interpretative perspective to explore individuals perception toward the symbolic meaning of the Ma'atenu ritual communication event.

Through the ethnographic method of communication, the benefits of the Ma'atenu ritual communication research in the digital era is that with the times and technology, it affects the 
mindset of the Pelauw Muslim community so that there is a shift in the value of tradition. The shift is developing from its original form. In the era of digital especially ritual communication will be more felt by anyone, because ritual communication and technology will influence and complement each other. Technology and ritual communication have an essential role in human life: technology, one component of ritual communication. Then the Pelauw Muslim community as a research subject is expected to enrich and develop communication theory, especially Ma'atenu and ritual communication which strengthen the scientific foundation in the development of communication science and the development of communication science roots. This research can also be a reference for other indigenous communities in the Moluccas, especially the Pelauw Muslim community who want to know Ma'atenu and make a reference to preserve this tradition.

The Ma'atenu performed by Pelauw people is regarded as a symbolic act in ritual communication. Society creates meanings that describe language and symbols to find the interpretation of ritual communication to understand and assess Ma'atenu. In addition, there is a link between communication, celebration and communality in the ethnography of communication with speaking methods from Dell Hymes, which focused on communication instead of language. Language lives in communication, and it will not have meaning without communication (Sulaeman \& Malawat 2018:136-137). It becomes the background of the research with the purpose is to understand the ritual communication of Ma'atenu. The research begins with elaborating understanding about the ritual communication events, subsequently by analysing the communication components. Finally, this research seeks the pattern of relationships between the components of Ma'atenu ritual communication.

The ethnographic approach to communication purposively used due to its primacy in describing human connection with performed rituals. This research expected to contribute to knowledge and references in developing communication science, particularly regarding communication ethnography in ritual communication of Ma'atenu communities in Pelauw. In addition, we envisioned our findings as reference for people in Pelauw to preserve cultural values through local wisdom Ma'atenu. This research can be a guidance for the public who wish to understand the essential values of Ma'atenu rituals.

\section{Research Method}

This study employs subjective constructivist paradigm with a qualitative approach to a community communication method in Pelauw Village, Haruku District, Central Maluku Regency, Maluku Province. We observe the patterns of interaction and communication in every ritual event in Ma'atenu. The type of this research is subjective, which utilised as a basis to describe the situation on Ma'atenu with interpretive subjective qualitative methods, focusing on observation and natural circumstances.

\footnotetext{
"Qualitative research takes place in natural condition, researchers regarded as research tools, uses qualitative methods (observations, interviews, and document review), inductive data analysis, descriptive methods, grounding theory, and concerned with process more than results, setting research limitation by deciding research focus, acquiring specific criteria for the data validity, employing temporary research design, and the results of the study have been mutually agreed between the researcher and the subject "(Moleong 2007:8-13).
}

Subjective interpretive qualitative research produces descriptive verbal or non-verbal and observation of people's actions (Sulaeman 2018:662-674). This method aims to maintain the form, content of action and analyse its quantity, rather than turning it into a qualitative entity (Mulyana 2018:150). As explained by Hymes (2018: 136-137), this research employs several stages through ethnographic communication research which listed as following: 1) identification of communication events that occur in Ma'atenu rituals, 2) inventory of communication components that build communication events in Ma'atenu, and 3) find patterns of relationships between the communication components that establish communication events, by bringing up communication patterns that involve the Pelauw community in Ma'atenu rituals. Ethnography of communication as a process that requires a long 
period of observation for a group, In addition, the process should undergo participative observation to uncover meaning and research subjects' point of view, event, or the observed process to enable researchers to dig deeper beyond statement and interview (Alwasilah 2003:155). A large number of informants and the long observation process in the Pelauw community had helped researchers to reveal the situation that observed.

Pelauw community has appointed as research focus during ethnographic of communication research (Kuswarno 2012:15) and listed as research informants are the chief of the land, ma'ahala lahat, ma'ataru ame, mother and or wife ritual performers. The community was chosen based on their essential characteristics and their comprehension about required information related to Ma'atenu and their rich experience for performing the rites. We obtained 17 informants who could share their communication experiences with researchers. The informants included one ma'ahala lahat, one ma'ataru ame, three chief of the land, three mothers and/or wives, and the remaining nine ritual performers originated from the western, southern and eastern area. Informants determined purposively based on consideration with a specific purpose (Bogdan \& Taylor 1998:163), who can provide information that will examine ritual communication to Ma'atenu.

During field observation, researchers acted as observers to categorises behaviour, observed symptoms, and recorded informants' speeches using media such as notes, cameras and tape recorders. It aimed to capture the thorough description of ritual Ma'atenu. In the beginning, researchers faced difficulties in conducting interviews due to researchers' ethnicity who were not Maluku, especially the Pelauw. Researchers were able to collect data from informants by showing patience and empathy for subjects. Interviews facilitated using local languages (Hatuhaha) through interpreters to smoothen the process and make the interview becoming intimate.

Research subjects were determined based on their ability and willingness to convey the experiences about Ma'atenu, especially the nature of rituals. Informants also were chosen based on their willingness in accepting the presence of researchers and involved in research activities, willingness to be interviewed and recorded during interviews and or the study. Informants selected through indepth interviews, participant observation and literature study. Interviews are an act of obtaining information by conducting question to gathered answer from informants. Lincoln and Guba explain interviews as a process of constructing people, events, organisations, feelings, motivations, demands, concerns, including constructing the past, projecting the future, verifying, changing, and extending information obtained from others (Moleong 2007:186). In the same disclosure, an interview is a form of communication between two people, involving someone who wants to obtain information from another person by asking questions based on specific objectives (Mulyana 2018:180).

In this study, researchers employed a structured interviews method. This method applied to explore informants' experiences, views, and knowledge about Ma'atenu. When researchers conducted the interview, informants will have the flexibility in using the structure of words and ideas to answer questions raised researchers. The results of data collection obtained from the field analysed in qualitative data processing method through the following steps: data reduction, data presentation, drawing conclusions and verification (Salim 2006:22-23). Researchers then draw the line between data interpretation according to the research question and research objectives. This verification is obtained by conclusions to answer communication events, communication components and the relationship patterns between the ritual components of Ma'atenu to finally be verified with other data or with the research subjects.

\section{Result and Discussions}

This section consists of three main subjects, namely communication events, communication components, and relationship patterns between the Ma'atenu rituals component of Pelauw.

\section{Communication event of Ma'atenu}

The communication event is a complete set of components involving participants with the standard general purpose of communication, variety of language, and rules of language (Kuswarno 2012:42). 
The Ma'atenu process is carried out by Pelauw community through communication events rites gathered at the clan house (small clan, parent clan, and merging clans), sacred tombs, self-cleansing actions, ritual communication acts, and giving fabric to ritual communication performers.

Table 1.

Interpretation of communication symbols in Ma'atenu

\begin{tabular}{|c|c|}
\hline Communication symbols & Interpretation \\
\hline $\begin{array}{l}\text { Clan house (little clan, parent clan and clan } \\
\text { intergration) }\end{array}$ & $\begin{array}{l}\text { Social solidarity and self-cleansing in the world } \\
\text { for their attitudes as dedication and respect to } \\
\text { ancestors. }\end{array}$ \\
\hline $\begin{array}{l}\text { - Staying over in clan house } \\
\text { - Shaving hair } \\
\text { - } \text { Bleeding or injured } \\
\text { - } \text { Ma'ahalat lahat } \\
\text { - Ma'ataru ame } \\
\text { - } \text { Carrying lahat fabric } \\
\text { - Water and white plate } \\
\text { - } \quad \text { Prater splash } \\
\end{array}$ & $\begin{array}{l}\text { - } \text { Communal solidarity } \\
\text { - Self cleansing } \\
\text { - Impure or not receiving family blessing } \\
\text { - Power consolidation } \\
\text { - Highest authority } \\
\text { - Bringing the presence of the ancestors } \\
\text { - The psychology of rites performers } \\
\text { - Blessing and self-cleansing } \\
\text { - Custom and religion contextualisation } \\
\text { - Safety, clarity, and power to rite's performers }\end{array}$ \\
\hline Sacred tomb & Allah representation \\
\hline $\begin{array}{l}\text { - } \text { Areca nut, betel leaf and calx } \\
\text { - Southing prayers to Prophet of Muhammad } \\
\text { - } \quad \text { Burning dammar gum }\end{array}$ & $\begin{array}{l}\text { - Respect to ancestors } \\
\text { - The spirit of struggle } \\
\text { - Plea to Allah }\end{array}$ \\
\hline Self-cleansing action & Eliminating bad behaviour \\
\hline Rite's communication event & $\begin{array}{l}\text { Self-immunity and power with the spirit of ancestors } \\
\text { through self cutting, stabbing stomach, chest, hand, } \\
\text { foot, neck, cheek, tongue, and head }\end{array}$ \\
\hline $\begin{array}{ll}\text { - } & \text { Upu Ana } \\
\text { - } & \text { Costumes } \\
\text { - } & \text { Red colour } \\
\text { - } & \text { Machetes, swords, and sharp objects } \\
\text { - Lahat fabric } \\
\text { - }\end{array}$ & $\begin{array}{l}\text { - Respect to ancestors } \\
\text { - Purity and self recumbence } \\
\text { - Sincerity and openness } \\
\text { - Persistency and bravery } \\
\text { - Struggling against the enemy } \\
\text { - The power of the soul } \\
\text { - Self mental support }\end{array}$ \\
\hline Fabric on the neck & Recovery to the normal state \\
\hline $\begin{array}{l}\text { - Salele fabric } \\
\text { - } \quad \text { Mothers and wives }\end{array}$ & $\begin{array}{l}\text { - Recovery and gratitude to Allah } \\
\text { - The source of life harmony }\end{array}$ \\
\hline
\end{tabular}

Sources: Researchers' observation and interview

\section{Clan house ritual}

Ma'atenu ritual communication emphasises the meaning of symbols on ritual events as a separate phenomenon for the Pelauw community. Society has a kinship relationship (Mansur 1988:16) which they called manikamu. Manikamu facilitates the ritual communication of Ma'atenu every three years. The last event held on Thursday, February 1, 2018. Initially, the Pelauw village government formed an implementation team to represent fourteen clans in Pelauw. The head of the clan communicates to Upu Ana, the grandchild of a particular clan of a daughter. Upu Ana has invited registrants from the village outside the village as Ma'atenu rituals performers. All registrants are proposed from each clan and designated as performers of the rite.

Ma'atenu ritual communication begins with the event gathered at the small clan house as a process of symbols identification. The performers are required to stay awake until the morning and shave their hair entirely. Performers stated particular words or displayed certain symbolic behaviours (Mulyana 2018:25). The symbol was to embody ideas and values related to hospitality, also as celebrations or of worship and fellowship. If the ritual performers were taking part in Ma'atenu for the first time, they would stay overnight in the house of a small clan and those who have previously participated in the ritual, return to their home and before come back to the small clan house. 


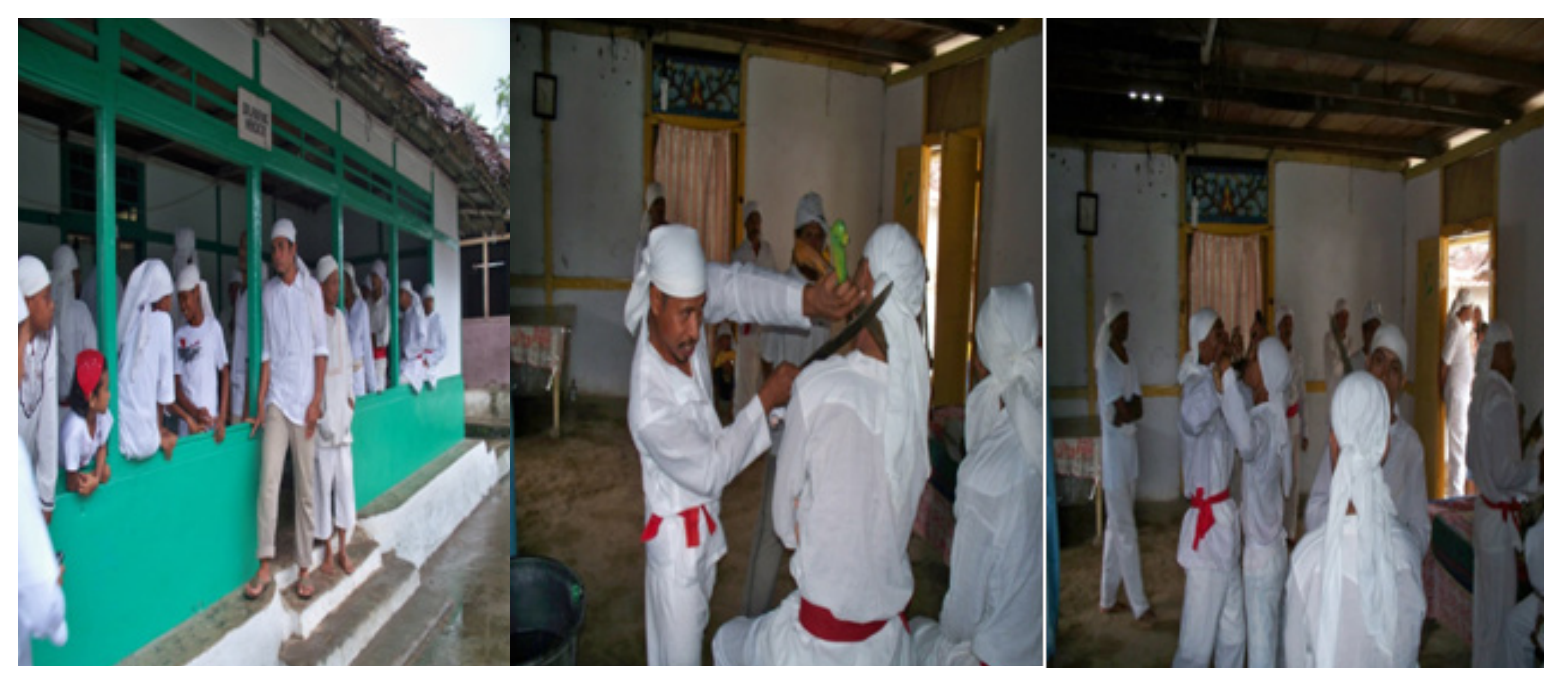

Figure 1.

Ma'atenu communication rituals act Sources: Researchers' archive (2018)

Communication events by staying overnight and shaving hair interpreted as the form of communal solidarity and self-cleansing as offerings to Allah, The Owner of the earth, also to obtain permission from Him. For the Pelauw people, staying at a small clan house and shaving their hair were interpreted as an identity, a reflection of togetherness to assert themselves as adherents of Islam. The ritual firstly carried out by gathering in a small clan house as a part of the elderly's house with the fourteen clans in Pelauw. The house divided into three clan sectors, and the gathering place has been arranged.

In the West Sector, the merger of the Latu clan includes the Latuconsina, Latupono, Latuamury, Talaohu, and Sahubawa clans. The five clans of the gathering place still separated from each other. The Talaohu and Sahubawa clans gather at the rumanai lesirohi, and the Latuconsina, Latupono and Latuamury clans gather at the rumani latuconsina. In the South Sector, urato roro rhima often called waelurui upstream of the Wae Marike river, and there are five clans domiciled in the mountains. They are the Salampessy, Angkotasan, Tuankotta, Tuakia, and Tualepe with their gathering place in Rumanai Tualepe. In the East Sector, there is Tuni Mahua Waelapia as a combination of Tuny Mahua with the Tuny, Tualeka, Tuahenka and Tuasikal clans gathered in a place called Tualeka Rumanai. At 06.00-06.30 on Thursday, February 1, 2018, all three clan sectors continued the ritual towards the main clan house, part of the large clan house occupied by clans, an elder from the male lineage in the old clan house of Tualepe. On the way to the main clan house, performers have carried out communication of ka'a condition while showing immunity and endurance using sword and machete, but the limbs do not experience injuries and bleed. If a member of the body suffers wounds and bleeds, performers were considered unclean and did not receive the blessing of the family, "Katong (we) apologised to one another with the family" (Fadli Latuamury), had a particular fault and had not yet resolved them while trying to join the Ma'atenu.

\section{Sacred tomb}

After gathering in the main clan house, the three clan sectors united in the Tualepe clan house to consolidate power while waiting for the arrival of Ma'ahala Lahat from the Tualepe clan. Ma'ahala Lahat will be the figure to lead the "supreme ruler" prayers. Ma'ataru Ame, an aide from Ma'ahala Lahat, will be the party responsible for evoking the performer of the ritual who has not yet experienced the conditions of $\mathrm{Ka}^{\prime} \mathrm{a}$ and bring the presence the ancestors. Ma'ahala Lahat leads performers, and Ma'ataru Ame enters one by one and sits in a circle to fill the available space to greet the chief of the clan. During the ritual, Ma'ahala Lahat carrying a lahat cloth (red cloth) which interpreted as communication psychology of the ritual performers.

Gathering in the main clan house is a process to identify nonverbal communication symbols displayed on performers' faces related to their psychological preparedness. In the ritual, performers created 
a circle with a white bowl filled with dialas water with a white plate in the centre. The property identified as a non-verbal communication that shows the blessing and purification of the ritual performers from Allah through the water and white plates as the media. The water was sprinkled on the head of ritual performers, symbolises the contextualisation of adat and religion. Ma'ahala Lahat led the prayer and recitation of the Prophet Muhammad's Salawat for performers' safety and wellness during the ritual. Recitation, the Salawat of Prophet, was followed by all the performers to provide calmness and strength for them.

Through the communication approach that uses the symbolic interactionism point of view, it is apparent that there is a process of shared meaning from the community that takes form in mutual understanding between member communities. There is also a communication process implemented by the communities by exchanging symbols (Halimah \& Kertamukti 2018:496) towards the ritual gather in the house of small clans and parent clans, and merged clans. The Pelauw people interpret that every human effort to gather in the house of a small clan and parent clan, as well as the merged clans, is an effort to create social solidarity and self-cleansing for their attitudes. The effort was also elucidated as dedication and respect for ancestors to examine individuals' ability to build harmonious solidarity, and not only with Allah Subhanahu wa Ta 'ala, but with each other. It is essential to affirm the existence of Islam as a religion, also acted based on local wisdom to practice Ma'atenu.

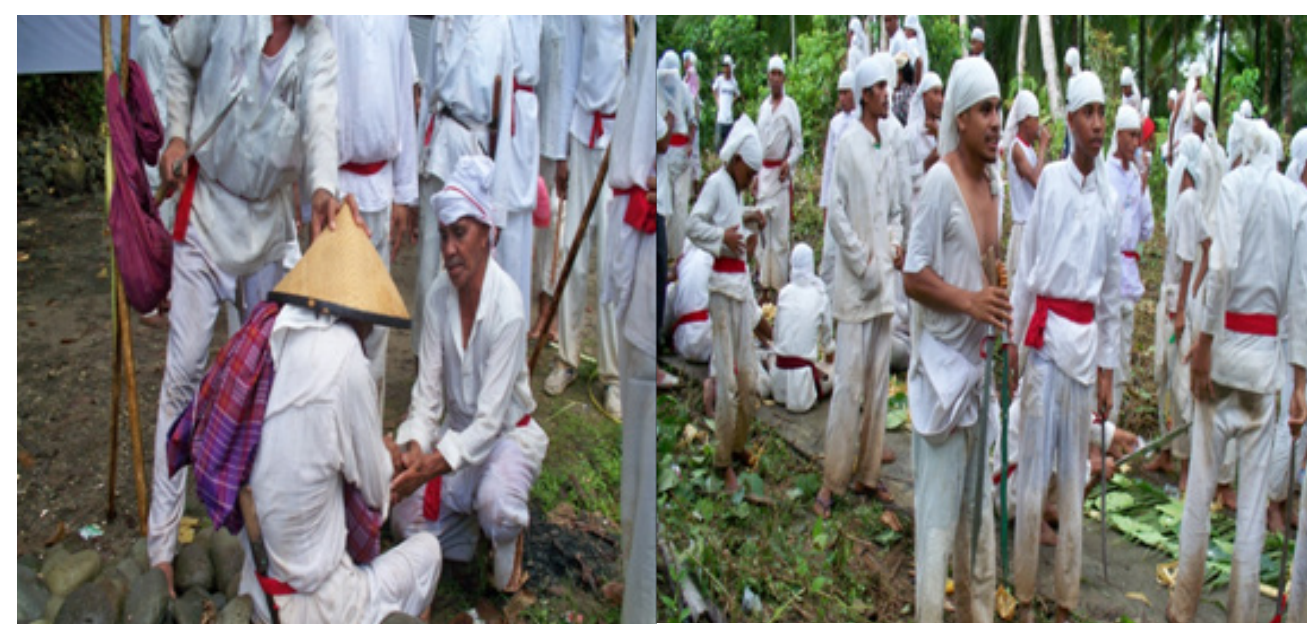

Figure 2.

Ma'atenu performers in a sacred tomb

Sources: Researchers' archive (2018)

After completing the ritual at the main clan house, around 10:00 Eastern Indonesian Time, performers started the trip to the sacred tomb. Performers perform rituals on pilgrimage to visit sacred tombs. Pilgrimage is a visit to a place considered sacred or noble (Choiron 2017:111). Therefore, the pilgrimage not to visit many places but a determined place that considered sacred such as a tomb or grave (Suyono 2007:147).

The three clan groups visit sacred tombs according to the clan sector. The western sector group, the Latu Rima appointed with the sacred of the Pelauw ancestors that located in Matasiri sacred tomb. For the eastern sector, Tuni Mahua Waelapia located in a village near the Waelapia River. Finally, the Southern Sector Group, Urato Roro Rhima, with the sacred tombs located in the headwaters of the Wae Marikee River, the most distant sacred tombs compared to the Matasiri and Waelapia. Pilgrimage to the sacred tomb was highly related to the elements of local wisdom and religion. Pelauw people believe the sacred tomb as a place for the burial of ancestral is where ancestral spirits stay. Pilgrimage to the tomb is a way to spiritually reconnected with these spirits (Woodward 1999:315).

The journey of the clan sector to the sacred tombs took approximately two hours. Performers of the ritual walk on an average 5-6 km into the forest to clean up the location of the sacred tombs. They will rest for a moment and waiting for the food distribution of food by women. The community believed that sacred tomb is the graves of the ancestors who spread Islamic teaching, as mentioned 
in the Koran Hujarat (49) verse 13. Ancestors' piety becomes a great lifestyle to be exemplified and used as a role model for the community. The pilgrims with their faith will feel close to the universe and try to obtain God's blessing by visiting people who are loved by God, even though that person has died (Choiron 2017:110).

The ritual communication events in the sacred tombs identified as rituals of prayer, led by Ma'ahala Lahat; ritual performers will conduct salvation prayers during the rituals. The prayer begin with the symbol of the offering of areca nut, betel leaf and lime as a tribute to the ancestors and often the performers of the chanting the prayer to Prophet Muhammad SAW. Ma'ahala lahat burns resin to plea to Allah Subhanahu wa Ta'ala also to respect Ancestors that have guarded the village and protected the Pelauw people. According to Azra (1999:66), Muslim communities in rural areas believe that Allah Subhanahu wa Ta'ala is has been very kind to the people, but at the same time, evil forces continue to bring disaster, so they are forced to direct their ritual activities to deal with evil forces. The people who have died believed as assistance in dealing with the forces of evil.

\section{Self-cleansing ritual}

The self-cleansing ritual held in-crowd, performers bathed in the river, which identified as a symbol of a communication event (Rahmawati et al. 2017:63). The Pelauw community perceived that the self-cleansing of individuals' lousy attitude is a good source of strength to make a plea to Allah and as the act of respecting ancestors.

Self-cleaning rituals is a communication media between Ma'ahala Lahat and ritual performers. The nonverbal communication of Ma'ahala lahat by performers' bath delivers messages about knowledge and awareness. In interpreting an object, physical characteristic is not the only element considered substantial. We can interpret the object from the collective or individual behaviour toward symbols. As stated by Mulyana (2015:83), basic human needs are focused on the needs of the symbol. In this event, Ma'ahala lahat regarded as a self-purification symbol that cleanses performers' soul so they will be able to execute the rituals with a pure intention.

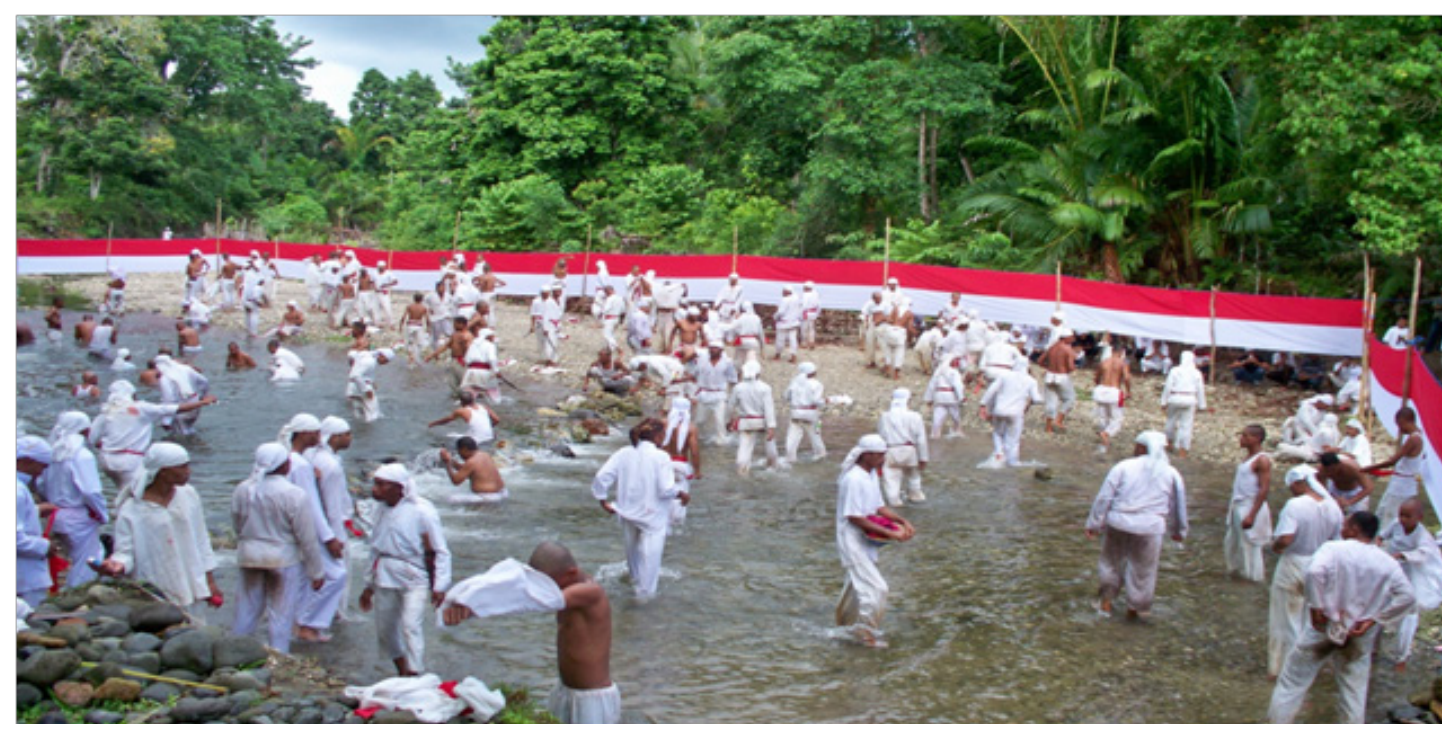

Figure 3.

Self-cleansing activities of Ma'atenu performers

Sources: Researchers' archive (2018)

\section{Ma'atenu communication act}

To be selected as Ma'atenu performers, several requirements should be fulfilled for performers candidates: 1) the heredity of the Latuconsina, Latupono, Latumury, Sahubawa, Talaohu, Salampessy, Angkotasan, Tuankotta, Tuakia, Tualepe, Tuny, Tualeka, Tuahenka, and Tuasical groups domiciled in the village or outside the village, 2) having intense commitment to make bound and togetherness, 
3) physically and mentally healthy, 4) obtaining blessing from family and wive, 5) shaving hair from the head, 6) maintaining verbal and psychological communication with family and the community, and 7) the ability to follow instruction such as cutting, slicing, and stabbing limbs using sharp objects.

In order to fulfil these requirements, performers should use non-verbal symbols, such as white shirt and trousers, red belts, and white headbands, machetes, swords and or other sharp objects (such as knives, razors, and axes), red lahat cloth, red salele cloth, tifa and tambourine to provide mental support and fighting spirit to Ma'atenu performers. The symbols had displayed since the beginning of ritual's trip from the house of a small clan, the main clan, the merged clan, the sacred tomb and finally to the square of the mosque and baileo.

The uniform used is a symbol of nonverbal communication indicating performers' neatness. The symbol interpreted as purity and the act to surrender to Allah Subhanahu wa Ta'ala to emphasise the existence of Islam. The white colour symbolises sincerity and openness of Pelauw people. Red belt symbolises determination and courage to defend and fight for self-identity. Sharp objects, such as machetes, swords, knives, razors, and axes as a medium of communication Ma'atenu, interpreted as resistance to fight against the enemy who threatens the Pelauw territory and its people. Lahat cloth symbolises the power of Ma'ahala lahat as a strength in the soul and as the symbol of safety for performers. Tifa and tambourine provided psychological support for performers and played in the entire trip from the small clan house to the Mosque and Baileo.

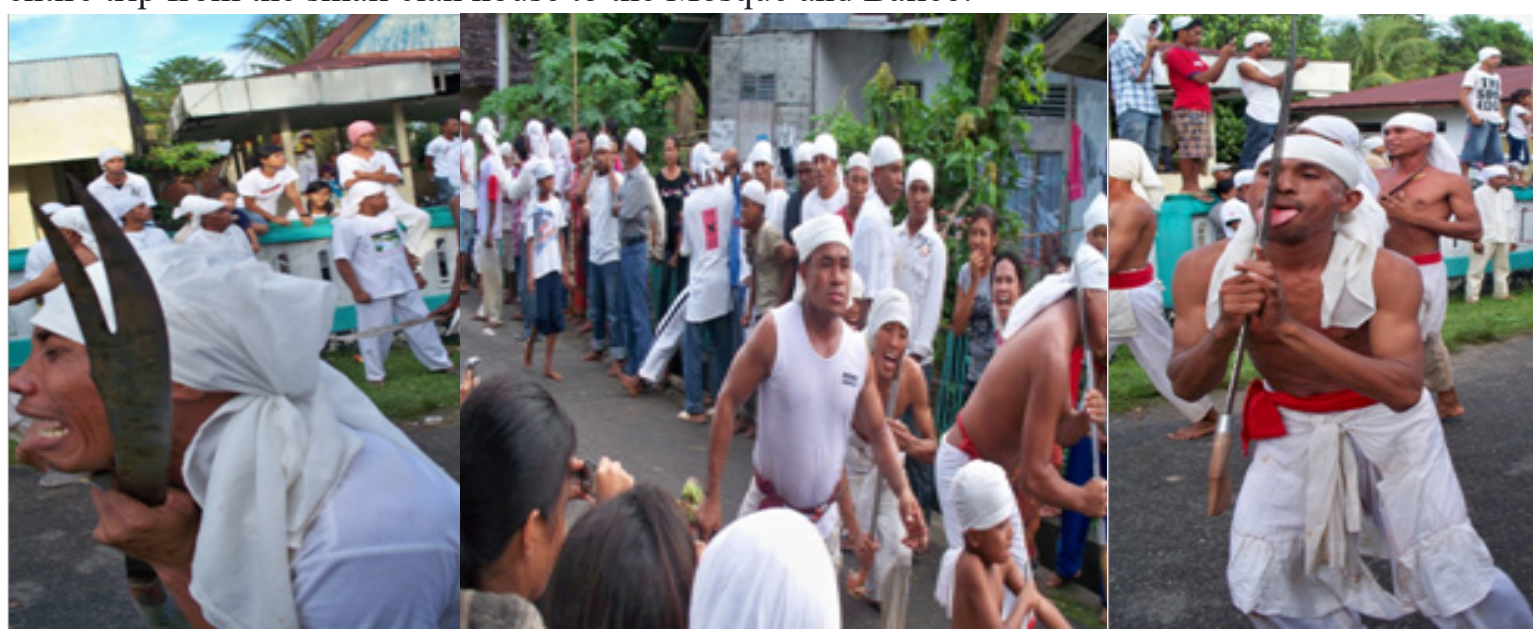

Figure 4.

Performers complete action during Ma'atenu

Sources: Researchers' archive (2018)

Ma'atenu ritual lasted for approximately one hour and a half. The event in the square was the peak activities of performers to test the immunity and strength of the ancestral spirits without their consciousness. Performers cut, slice and stab their abdomen, chest, hands, feet, neck, cheeks, tongue and head with machetes, swords and or other sharp objects. Their spirits livened up through the sound of drums and tambourines. The actions displayed in Ma'atenu is a symbolic communication system which interpreted as guidance for morals and behaviour, also to strengthen emotional relations (Humaeni 2015:185). This ritual is believed as a place to plea to God, to respect, and to show social solidarity among members of the community in guarding territory and emphasise selfidentify as adherents of Islam. The rituals also aim to increase the strength and spiritual patience to ask for help for Allah Subhanahu wa Ta'ala in facing problems when their territory and self-identity was disturbed. The fulfilment identity as a member the clan that every Pelauw community realises existence in the context of how to interact with Allah Subhanahu wa Ta'ala, ancestors, and the community, as well as maintaining continuity of Ma'atenu rituals.

\section{The act of communication of giving fabric to performers}

Performers entered baileo as the last destination of the whole Ma'atenu process. Baileo is believed to be a place to restore performers condition after being possessed by ancestral spirits into their normal 
conditions. Dhavamony (1995:175) distinguishing ritual acts as following: 1) magical actions are associated with the use of materials because of mystical power, 2) religious and cultic actions of the ancestors, 3) rituals to express social relations and referring to mystical notions, and 4) rituals that increase productivity, strength, purification and protection. In the case of $M a^{\prime}$ 'atenu, performers were not injured nor bleed. This ritual is a communication event held by hanging a red Salele cloth to the neck of performers. Performers entered Baileo one by one. They have been expected by several middle-aged women in cloth and kebaya. Women stood at the entrance of East Baileo welcomed them by hanging a Salele cloth. The cloth believed helped the recovery of performers to their normal conditions after ancestral spirits possession. The Salele cloth underlies the relationship between humans and rituals as an understanding of their local wisdom.

The act of carrying the cloth symbolises the end of the Ma'atenu ritual as the process of restoration and express gratitude to Allah Subhanahu wa Ta'ala. The rituals aim to honour the nobility and solidarity of the descent of Pelauw that had conducted the ritual. In addition, the role of the family, such as mothers and/or wives, has been occurred since the preparation stage until the Salele cloth giving to performers. Boys and/or husbands as ritual performers need to get the blessing from mothers and/or wives as one of the ritual requirements. Mothers and/or wives present at Baileo are representatives of all Pelauw women, accepting performers as their children and husbands and becoming the source of life harmony and strength for Pelauw Muslim men.

A true Pelauw people will perceive Ma'atenu as an awareness to portray themselves as creatures of Allah Subhanahu wa Ta'ala. The awareness and knowledge about their existence transformed into a guidance to build, cultivate, and develop harmonius interaction between human. Such relations is an embodiment of supplication to Allah, respect to ancestors, and creation of social solidarity in the community. The pattern is an interaction and communication mechanism that should be accomplished in Ma'atenu. Ma'atenu is frequently associated with hereditary actions of the Pelauw people, formal actions with religious and customary values. This ritual is understood as a voluntary performance based on a patterned-behavior. Ma'atenu offers new values that can arouse a sense of social solidarity. The method is to strengthen religious values and principles of life. The ritual is an essential media for the local policy to uphold the existence of Islamic ideology and reject the presence of invaders Pelauw. The rejection transformed into communication event of Hatuhaha War. Testing the immunity and courage of Pelauw men as a visualisation of maintaining the existence of the village, pleading to Allah Subhanahu wa Ta'ala, honoring ancestors and building social solidarity among the Pelauw community.

\section{Communication component of Ma'atenu}

Based on the communication event, researchers identified 11 communication components, as stated by Dell Hymes (Sulaeman \& Malawat 2018:136-137). These components portrayed in the context of Ma'atenu rituals in Pelauw. The first component is 'genre type of event' which interpreted as a communicative event. Ma'atenu conducted through whole communication event such as gathering in clan house, visiting the sacred tomb, self-cleansing act, communication rituals act, and giving fabric to Ma'atenu performers. Those events have their interpretation of the symbol and are complementary to each other.

The second component is the topic or referential focus as a focus of the exchanged symbols. The topic of Ma'atenu communication rituals is to test the immunity and power in enacting Islamic ideology. The form of immunity and power proven by cutting, slicing, stabbing performers> body part such as stomach, chest, hand, foot, neck, cheek, and head with sharp objects. The third component is the purpose or function. Ma'atenu rituals performed every three years. The last event held in February first, 2018. The rituals planned in one month. The initial phase is the formation of a team that represents 14 clans of Pelauw. Each head of the clan communicates to Upu Ana which invited as an act of honour for performers' candidates to register themselves, whether they domiciled in the village or outside the village. All candidates were proposed from each clan and decided as communication rituals performers. They asked Allah Subhanahu wa Ta'ala for supernatural power 
which they believed is the embodiment of God, the power of ancestors which unconsciously give them immunity and power. The supernatural power created community relations as a system of belief with a unique interpretation of religion - such sense in essential to build universal solidarity in the community, especially in Pelauw. The rituals aimed to obtain blessing and safety in Pelauw's people daily life, also to erect Islamic teaching in the area.

The fourth component is the set of physical aspect in a communication such as location, time, season, space, or room layout. The setting is a language component refer to space, time, and schedule of Ma'atenu. The fifth component is the key or emotional tone of the event, related to the tone people used for communication. This component related to the use of language, the relations between actors, and the message they want to deliver. Ma'atenu uses a local language called "hatuhaha" during the event. The sixth component is the participant. Participant of communication is individuals involved in a process or communication act, including age, sex, ethnicity, social status, or other characteristics which have bonded to each other. Ma'atenu involves the King of Pelauw called Ma'ahala Laha, Ma'ataru Ame, parents, and wives. Performers have selected men to represent the clan of Latuconsina, Latupono, Latuamury, Talaohu, Sahubawa, Salampessy, Angkotasan, Tuankotta, Tuakia, Tualepe, Tuny, Tualeka, Tuahenka, and Marga Tuasikal.

The seventh component is the message form, as a verbal or non-verbal communication media and the essence of the used code in a communication. Ma'atenu utilised a verbal channel between Ma'ahala Laha and the performers through ancestral power and immunity. Ma'ahala Laha in a praying position while carrying the Lahat fabric, assisted by Ma'ateru Ame which responsible to bring the ancestral spirit presence to possess performers. Non-verbal communication tends to interpret symbols as local wisdom. Symbols were created from local power based on the honour of ancestors to enhance Islamic ideology. The symbols are preserved by Pelauw people every three years through Ma'atenu rituals.

The eight component is the message content. A message carries ideas and feeling from individuals interpreted through symbols. For instances, language becomes a communication message to another person. A message can be verbal or non-verbal and emphasise the essence of the applied code. The ritual communication delivered in the verbal method through prayers and Shalawat to Prophet of Muhammad SAW that conducted at the beginning of the rituals. Ma 'ahala Laha leads the prayer. The non-verbal component during the prayers have occurred in rituals such as bringing water and white plate, areca nut, betel leaf, and burning damar,

The ninth component is the action sequence. The sequence of communicative measure including the pattern and conversation the ritual, including who initiated the conversation and the following sequence. Communication event in Ma'atenu arranged din formal rules. Pelauw people implement the rules through various applied norms and the tradition to plea to God, respect and honour, and social solidarity.

The tenth component is the rules of interaction. The rules of interaction are the rules of applied language that must be considered when carrying out ritual communication on Ma'atenu. The Ma'atenu ritual activity is a three-year rite that results in an appreciation of the values of order in the Pelauw people. The value to respect is high that build a strong sense of social solidarity among the people in the village and outside Pelauw village. Ma'atenu containing religious values and becomes a medium of communication with the power of the ancestors and the highest power of Allah Subhanahu wa Ta'ala to uphold the ideological teachings of Islam. For Pelauw people, Ma'atenu rituals are a medium of communication. Their relationships built by fulfilling the rules of Allah Subhanahu wa Ta'ala through respecting ancestors of strength and immunity. The act embodied during ritual communication events through the following activities: gathering at clan houses, visiting sacred tombs, self-cleaning actions, ritual communication acts, and wearing red cloths. The event of ritual communication has provided performers with immunity and power through Ma'ahala laha prayers.

The eleventh component is the norm of interpretation aThe norm of interpretation including shared knowledge, culture, values and norm. The custom of Ma'atenu is wearing white cloth such as 
white cloths and pants, pants, belts, and headbands. Another habit is the use of sharp objects as communication media, such as machetes, swords, knives, razors and axes. The norm adopted by the Ma'atenu ritual is to have emotional commitment to construct a sense of togetherness, to have physical and mental health, and to obtain a blessing from the family or wife of the ritual performer. Commitment and blessing are to cleanse performers and to prepare them in completing the acts of ritual communication of the sacred Ma'atenu's ritual.

The sacred value of Ma'atenu is the supernatural power and immunity of performers. The rituals have been inherited through generations, and sharp objects have extraordinary power. The values of Ma'atenu needs to be preserved to erect the ideology of Islam in Pelauw, also to build communal solidarity of Pelauw community.

\section{Ritual communication pattern of Ma'atenu}

Pelauw people perform rituals as a media to communicate to Allah Subhanahu wa Ta'ala and their ancestors. They perceive Ma'atenu as a knowledge system that represents the cognitive aspect. Rituals have become a method to build, to develop, and to preserve the sense of solidarity between people. According to Carey (Sulaeman 2016:18), communication rituals related to the ceremony held by a community. Rituals conducted collectively and regularly to remind the people about collective values and shared-knowledges of their culture, including the methodological aspects, theory, practice. People will interpret and react based on the symptom they received.

Based on the communication ritual point of view, Carey (Sulaeman 2016:29) added that communication is a process to transform local wisdom. In other words, there is a process to comprehend and interpret the character of local wisdom. People see local wisdom for further identification, interpretation, and creation of a specific behaviour based on their observation. The focus of this process is the adaptation context with the final goal is to build and maintain solidarity. Couldry (Sulaeman \& Malawat 2018:32) explained the communication pattern of a ritual is not about messengers send message to the receiver, but as a sacred ceremony where all individuals take part and gather to celebrate it.

The local community carry out the process to interpret and categorised various communication events in Ma'atenu. They also bring up various types of prayer, the sense of respect for ancestors, solidarity among people, and a plea to Allah Subhanahu wa Ta'ala. Each individual and/or community carries out its interpretation of the symbols, although the results of this interpretation highly influenced by various sources, such as parents stories, stories of villagers, and their own communication experiences. The results of the meaning can not stand alone, and it is highly related to the influence of other groups which then becomes a shared meaning. Mead has confirmed in Mulyana (Sulaeman \& Malawat 2018:75) that meanings are arises from its interactions with other humans. The process is known as symbolic, with a process to interpret the cultural symbols.

The ritual communication process in the Pelauw community occurred as a consequence of the relationship between each element of the communication agent. Elements of ritual communication practitioners bind all these processes. A child will be bound by the experiences conveyed by his parents, either in the form of direct speech, stories telling, parents' request for the child to be involved in the ritual, or seeing the ritual firsthand. If such circumstances do not happen, the meaning agreement will be different, and the integrity of the ritual communication community will be disrupted.

The communication process in Ma'atenu close and intimate and connects to ritual communication events of Ma'atenu. Relationship level and emotional closeness are essential factors in Ma'atenu. This factor is closely related to the customary context of the Pelauw community and the kinship level. It believed that Pelauw community is an indigenous community who still maintain a culture based on the Islamic religious beliefs they profess. Hadikusuma (Sulaeman 2016:65), stated that indigenous people as a community that interacts with each other according to specific custom systems, continuously intertwined and bounded by a shared identity. Pelauw communities are essential to understand various perceptions of local wisdom to developing in the form of Ma'atenu ritual communication strategies. 
Ma'atenu rituals confirm the situation. The activities of cutting, slicing, and stabbing a limb, a conscious act performed intentionally to give a specific message. This action has a religious value which has certain religious functions (Mulyana 2015:49), transcendental communication is communication that takes place between ourselves and the magical aspect. It presents a social reality that is still alive and maintained today in various regions in Indonesia. Therefore, transcendental communication is not only about religious perspective, but also a cultural perspective.

To understand transcendental communication, Mulyana (2015:49) mentioned that communication is the process of creating meaning between two or more people through the use of symbols or signs. In transcendental communication, the participants are humans and God. The local meaning or logic behind the ritual of cutting, slicing, and stabbing the body part means all intents and purposes that conveyed and accepted to fulfil identity to ask for Allah's guidance. Mulyana (2015:49-50) added that the core of the communication process is perception consists of the internal process which humans choose, evaluate, organise and interpret from their surroundings. Communication becomes equal when through the ritual communication event in Pelauw.

The ritual communication in the form of prayer always begins with a tribute to ancestors, solidarity among people, and a request to Allah Subhanahu wa Ta'ala to obtain blessings. Pelauw people have their mechanism in conducting ritual communication through prayer that can secure the continuity of their social order. Social order as a symbolic process, the act to mutually interpret symbols, the relation to the symbol continues intended for the presence of Ma'atenu process. This ritual arranged in the form of a plea to God, respect, and solidarity, interpreted as the attitude of the Pelauw people and how they should behave towards the struggle ancestors.

The Pelauw community is aware of its existence which is highly associated with Islamic beliefs. Pelauw's culture contains the values of unity which generates a strong sense of social solidarity among the people. The value of unity contained in the ritual is related to the sacred events of Ma'atenu. This ritual has a sacred and noble goal to increase and to encourage awareness in building and maintaining social solidarity among the community. The rituals also preserve the integrity of the Pelauw village to conduct Ma'atenu.

They are maintaining Ma'atenu as the embodiment of social solidarity among people. Social solidarity creates the value of unity while religious value and creates stability in the social life of the community. Unity and religion as a process of mutual communication for the community in creating social situations are essential to create harmonious cooperation. Ritual as a corporate communication for the community also creates social meaning in the form of values, also to increase the community self- esteem. These values create peace and stability in the social life of the community.

\section{Conclusion}

This research has analysed the Ma'atenu communication rituals of Pelauw people. All activities in Ma'atenu symbolises the people eagerness to serve, struggle, alleviate bad attitude, gain power and immunity, and self-recovery.

The communication events analysed using the Dell Hymes speaking method. The data was analysed based on communication components that form Ma'atenu ritual communication pattern to the Pelauw community. The communication pattern of plea to Allah Subhanahu wa Ta'ala, respect for ancestral spirits and create social solidarity among people. This communication pattern, like collective action, contains transcendental elements that loaded with sacred values, tendencies of symbols and its embedded meanings.

The recommendations of this research are to emphasise the continuity of the issue from a different approach. A qualitative approach with a different method is expected to strengthen the findings. There is much space for prospective research, for instance, is the life experience of Ma'atenu performers. For example, that the perpetrators of ritual communication use nonverbal media (sharp objects, 
such as machetes, swords, knives, razors) to stab, cut, and slice the entire body, do not bleed and/ or suffer injuries. Through a phenomenological perspective, they can explore their communication experiences. The process of ritual communication carried out by the Pelauw community needs to be preserved and introduced to the broader community. Researchers expected for government intervention to promote Ma'atenu as cultural tourism to benefits to the Pelauw community, as well as improving the level of economic prosperity.

To policymakers from the middle level to the regions and policy implementers on the local level should obtain essential knowledge about the views, feelings and the need of Pelauw people. With suitable regulation, policymakers can maintain Ma'atenu against claims of cultural ownership.

\section{References}

Alwasilah AC (2003) Pokoknya Kualitatif: Dasar-Dasar Merancang dan Melakukan Penelitian Kualitatif. Bandung: Pustaka Jaya.

Azra A (1999) Renaisans Islam Asia Tenggara Sejarah Wacana dan Kekuasaan, Bandung: Remaja Rosda Karya.

Bogdan R \& Taylor SJ (1998) Introduction to Qualitative Research Methods: A Phenomenological Approach to the Social Science. New York, John Wiley and Son.

Choiron AH (2017) Menggali makna ziara di Makam Mursyid Toriqoh Syekh Mutamakin Kajen dalam perspektif konseling tasawuf. Konseling Religi: Jurnal Bimbingan Konseling Islam 8 (1):107-131. doi: 10.21043/kr.v8i1.2268.

Dhavamony M (2000) Fenomenologi Agama. Yogyakarta: Kanisius.

Foni W (2004) Budaya Bertani Atoni Pah Meto: Siklus Ritus Bertani Lahan Kering Atoni Pah Meto Tunbaba Timor, Nusa Tenggara Timur. Salatiga: Program Pascasarjana Universitas Kristen Satya Wacana.

Haliemah N \& Rama K (2017) Interaksi simbolis masyarakat dalam memaknai kesenian jathilan. Jurnal Aspikom 3 (3):495-507. DOI: 10.24329/aspikom.v3i3.173.

Humaedi MA (2017) Penelitian etnografi di balik pencegahan konflik dan affirmative action perlindungan kekayaan budaya: Memahami sebuah hibriditas kebudayaan. Jurnal Mayarakat dan Budaya 19 (3):447-467. DOI: 10.14203/jmb.v19i3.544.

Hymes D (1972) Models of the Interaction of Languege and Social Life. New York: Holt, Rinehart \& Winston.

Kasnadi (2017) Nilai religi: Sebuah kearifan lokal dalam cerita rakyat Ponorogo. IBDA' Jurnal Kebudayaan Islam 15 (1):149-179. DOI:10.24090/IBDA.V15I1.736.

Kuncoroyakti Y (2018) Komunikasi ritual Garebeg di Keraton Yogyakarta. Jurnal Aspikom 3 (4):623634. DOI: 10.24329 /aspikom.v3i4.189.

Kuswarno E (2012) Etnografi Komunikasi suatu Pengantar dan Contoh Penelitiannya. Bandung: Widya Padjadjaran.

Leuape ES \& Susanne D (2017) Dialetika etnografi komunikasi emik-etik pada kain tenun. Jurnal Kajian Komunikasi 5 (2):147-158. DOI: 10.24198/jkk.v5i2.8637.

Littlejohn SW \& Foss KA (2010) Theories of Human Communication. California: Belmont.

Mansur Y (1988) Sistem Kekerabatan Masyarakat dan Pola Kewarisan, Cet.I. Jakarta: Pustaka Grafika.

Moleong J L (2007) Metodologi Penelitian Kualitatif. Cet.XXIV. Bandung: PT. Remaja Rosdakarya.

Mulyana D (2015) Nuansa-Nuansa Komunikasi Meneropong Politik dan Budaya Komunikasi Masyarakat Kontemporer. Bandung: Remaja Rosdakarya.

Mulyana D \& Sulaeman (2016) People with lobster-claw syndrome: A study of oligodactyly sufferers and their communication experiences in the Village of Ulutaue, South Sulawesi, Indonesia. Mediterranean Journal of Social Sciences MCSER Publishing 7 (1):136-144. 10.5901/ mjss.2016.v7n1s1p136. 
Mulyana D (2018) Metodologi Penelitian Kualitatif: Paradigma Baru Ilmu Komunikasi dan Ilmu Sosial Lainnya. Cet.IX. Bandung: PT. Remaja Rosdakarya.

Rahmawati R, Nurhadi ZF, \& Suseno NS (2017) Makna simbolik Tradisi Rebo Kasan. Jurnal Penelitian Komunikasi 20 (1):61-74. DOI:10.20422/jpk.v20i1.131.

Rumahuru YZ (2012) Ritual Ma'atenu sebagai media konstruksi identitas komunitas Muslim Hatuhaha di Pelauw Maluku Tengah. Jurnal Kawistara 2 (1):36-47. DOI:10.22146/kawistara. 3949.

Salim A (2006) Teori dan Paradigma Penelitian Sosial. Yogyakarta: Tiara Wacana.

Sakka L (2015) Tarian Ma'atenu di Pulau Haruku Kabupaten Maluku Tengah. Jurnal al-Qalam 21 (2):291-302. DOI: 10.31969/alq.v21i2.232.

Sulaeman (2016) Komunikasi Lingkungan: Fenomena Hutan Suku Naula di Pedesaan, Cet. I. Ambon: LP2M IAIN Ambon.

Sulaeman \& Sulastri I (2017) Motif Da'i berdakwah di Kota Ambon. Afkaruna: Indonesian Interdisciplinary Journal of Islamic Studies 13 (2):240-264. doi: 10.18196/AIIJIS.2017.0074.

Sulaeman \& Malawat M (2018) Bakupukul Manyapu: Komunikasi Ritual Masyarakat Adat Mamala, Cet. I. Ambon: LP2M IAIN Ambon.

Sulaeman (2018) Dramaturgi penyandang oligodaktili. Jurnal Aspikom 3 (4):662-674. doi: 10.24329/ aspikom.v3i4.270.

Sulaeman \& Rijal M (2018) Environment communication: Symbolic meaning of forest of tribal peoples of Naulu Central Moluccas. The Social Sciences 13 (5):1006-1013. DOI:10.3923 / science.2018.1006.1013.

Suyono CRP (2007) Dunia Mistik Orang Jawa: Roh, Ritual, Benda Magis, Cet. I. Yogyakarta: LKiS. Woodward MR (1999) Islam Jawa: Kesalehan Normatif versus Kebatinan, Cet. I. Yogyakarta: LKiS. 